\title{
Influence of untreated chronic plastic iridocyclitis on intraocular pressure in leprosy patients
}

\author{
Murat A Karaçorlu, Tülay Çakiner, Türkan Saylan
}

\begin{abstract}
The intraocular pressures of a total of 286 eyes of patients with lepromatous and borderline lepromatous leprosy who never had regular ophthalmological care or local eye treatment were measured. The patients were categorised according to the type of leprosy they had, and the eyes were categorised as without or with chronic plastic iridocyclitis. In patients with lepromatous and borderline lepromatous types of leprosy the intraocular pressure was significantly lower in eyes with chronic plastic iridocylitis $10.1(3.6) \mathrm{mmHg}$ than in both unaffected eyes $11.0(3.2) \mathrm{mmHg}$ and control eyes $13.5(2.5) \mathrm{mmHg}$. It has been shown that chronic plastic iridocyclitis which remains untreated for years results in a lower intraocular pressure than normal.
\end{abstract}

In leprosy patients chronic plastic iridocyclitis (CPI) affects ocular physiology gradually and as a consequence may lead to lesions causing complicated cataract and phthisis bulb. ${ }^{12}$ There has been only one study questioning the effect of CPI on intraocular pressure (IOP) in leprosy. ${ }^{3}$ In this study the Schiøtz tonometer was used, and, since the study was carried out in rural areas in Nepal, a biomicroscope was not available and only synechiae were used as the diagnostic criteria of CPI. It is difficult to make accurate measurements under conditions of very low pressures with the Schiøtz tonometer. Moreover, in the above mentioned study the diagnosis of CPI was based on insufficient criteria. For these reasons the accuracy of the results may be questioned.

The low prevalence of leprosy in Turkey and its being not well known has caused delay in establishing the diagnosis and beginning treatment. ${ }^{4}$ This delay has been presumed to be 5-10 years (personal communication, Saylan T, 1986). We know that in leprosy the first symptoms of ocular involvement appear approximately five years after the onset of the disease, and therefore a number of patients in our country have attacks of leprous uveitis of short or long duration before diagnosis of leprosy has been established. If it is remembered that chronic leprous uveitis is not a cause of much complaint, we may realise what kind of risks these patients run. Apart from this

Table 1 Ages and duration of the disease of the patients with lepromatous leprosy $(L L)$ and borderline lepromatous leprosy $(B L)$

\begin{tabular}{|c|c|c|c|c|c|c|c|c|}
\hline & \multicolumn{4}{|c|}{ Age (yr) } & \multicolumn{4}{|c|}{ Disease duration $(y r)$} \\
\hline & $<20$ & $20-40$ & $>40$ & Total & $<10$ & $10-20$ & $>20$ & Total \\
\hline $\begin{array}{l}\text { Lepromatous } \\
\text { Leprosy (LL) } \\
\text { Borderline } \\
\text { Lepromatous } \\
\text { Leprosy (BL) }\end{array}$ & $\begin{array}{l}8 \\
4 \cdot 5 \% \\
4 \\
3 \cdot 6 \%\end{array}$ & $\begin{array}{l}78 \\
44 \cdot 4 \% \\
50 \\
45 \cdot 4 \%\end{array}$ & $\begin{array}{l}90 \\
51 \cdot 1 \% \\
56 \\
50 \cdot 9 \%\end{array}$ & $\begin{array}{l}176 \\
110\end{array}$ & $\begin{array}{l}58 \\
33 \% \\
34 \\
30 \cdot 9 \%\end{array}$ & $\begin{array}{l}40 \\
22 \cdot 7 \% \\
36 \\
32 \cdot 8 \%\end{array}$ & $\begin{array}{l}78 \\
44 \cdot 3 \% \\
40 \\
36 \cdot 3 \%\end{array}$ & $\begin{array}{l}176 \\
110\end{array}$ \\
\hline
\end{tabular}

one cannot claim that complete and regular leprosy therapy was carried out in our country before 1983. Only after that year was regular, modern leprosy therapy with a variety of drugs started. If we consider that the mean duration of disease has been about 20 years in the lepromatous leprous (LL) and borderline leprous (BL) patients we have been following up, we may conclude that in some of our patients the disease has been undiagnosed and without treatment for a long time.

In this study, because of the above mentioned reasons, the IOPs of our leprosy patients who have long been left untreated have been measured by applanation tonometer in a prospective but non-random and unmasked study, and the effect of CPI on the IOP has been investigated.

\section{Materials and methods}

The study was carried out from June 1986 to the end of 1989 by the Department of Ophthalmology, Cerrahpaşa School of Medicine, University of Istanbul, and Istanbul Leprosy Hospital and Research Centre. It included 286 eyes of 143 leprosy patients, 88 of whom had lepromatous leprosy (LL) and 55 borderline lepromatous leprosy (BL). As the control group, 48 eyes of 24 adults were taken, matched by age to the study group, who had not had any ocular or systemic diseases, and who were not receiving topical or systemic medication.

The type of leprosy was diagnosed according to the Ridley-Jopling ${ }^{5}$ classification of clinical, microbiological and histological criteria in the Istanbul Leprosy Hospital. The diagnosis of chronic plastic iridocyclitis was established when keratic precipitates, posterior synechiae, sequelae of posterior synechiae, iris atrophy, or iris pearl were detected.

The systemic leprosy treatment of 76 of the cases $(53 \cdot 1 \%)$ was terminated before they were included in the study. Sixty seven of them $(46.9 \%)$ received multidrug leprosy treatment DDS (dapsone or disulone)+rifampicin+ prothionamid (promid), or alternatively clofazimine (lamprene) - when they were included in the study.

The mean age of the control group was $\mathbf{4 0 . 7}$ $(12 \cdot 3)$ years, and that of leprosy patients ( $L L+$ BL) $41.5(13.4)$ years. The mean duration of the disease in patients with leprosy was $19 \cdot 7(12 \cdot 2)$ years. The ages and the duration of the disease of the patients with $L L$ and $B L$ are shown in Table 1.

The ophthalmic examination of the leprosy patients included examination of the anterior segment by biomicroscope. Their IOPs were measured by Goldmann applanation tonometer. The findings have been recorded on a form. 
Table 2 Distribution of the intraocular pressure in 286 eyes of patients with lepromatous leprosy and borderline lepromatous leprosy

\begin{tabular}{|c|c|c|c|c|c|c|c|c|c|c|c|}
\hline & \multicolumn{11}{|c|}{ Intraocular pressure $\mathrm{mmHg}$} \\
\hline & $3-5$ & $6-7$ & $8-9$ & $10-11$ & $12-13$ & $14-15$ & $16-17$ & $18-19$ & $20-21$ & $\geqslant 22$ & $\begin{array}{l}\operatorname{Mean}(S D) \\
\operatorname{IOP}(\mathrm{mmHg})\end{array}$ \\
\hline $\begin{array}{l}\text { CPI }(+) \\
n=118\end{array}$ & $7(5.9)^{\star}$ & $16(13 \cdot 6)$ & $35(29 \cdot 7)$ & $28(23 \cdot 7)$ & $17(14 \cdot 4)$ & $9(7 \cdot 6)$ & $2(1 \cdot 6)$ & $1(0 \cdot 8)$ & $1(0 \cdot 8)$ & $2(1 \cdot 6)$ & $10 \cdot 1(3 \cdot 6)$ \\
\hline $\begin{array}{l}\text { CPI }(-) \\
n=168\end{array}$ & $5(3 \cdot 0)$ & $18(10 \cdot 7)$ & $28(16 \cdot 7)$ & $49(23.9)$ & $32(13 \cdot 8)$ & $22(12 \cdot 9)$ & $6(3 \cdot 5)$ & $4(2 \cdot 3)$ & $4(2 \cdot 3)$ & - & $11 \cdot 0(3 \cdot 3)$ \\
\hline $\begin{array}{l}\text { Total } \\
n=286\end{array}$ & $12(4 \cdot 2)$ & $34(11 \cdot 9)$ & $63(22 \cdot 0)$ & $77(26.9)$ & $49(17 \cdot 1)$ & $31(10 \cdot 8)$ & $8(2 \cdot 8)$ & $5(1 \cdot 8)$ & $5(1 \cdot 8)$ & $2(0 \cdot 7)$ & $10 \cdot 6(3.5)$ \\
\hline
\end{tabular}

^The figures in brackets show the percentage values.

\section{Results}

The distribution of the IOP in patients with leprosy who had or had not established findings of CPI are shown in Table 2.

The mean (SD) IOP was $10 \cdot 1(3 \cdot 6) \mathrm{mmHg}$ in leprosy patients with $\mathrm{CPI}$, and $11 \cdot 0(3 \cdot 3) \mathrm{mmHg}$ in those without established CPI. The mean IOP of the control group was $13.5(2.5) \mathrm{mmHg}$ The mean IOP of leprosy cases with established CPI findings was significantly lower than the IOP in either the cases without established CPI or of the control group $(p<0.05)$ and $(p<0.001)$. Moreover, the difference between the eyes without $\mathrm{CPI}$ and the control group was significant $(\mathrm{p}<0.05)$.

When the relation between the duration of leprosy and IOP was investigated, the mean IOP was found to become lower as the duration of the disease was longer. The mean IOP of patients who had had leprosy for more than 15 years was significantly lower than in patients with leprosy for 0.5 years $(p<0.005-0.001)$ (Table 3 ).

When the distribution of the lower IOPs was investigated the IOP was below $10 \mathrm{mmHg}$ in seven eyes (14.5\%) in the healthy control group, whereas this proportion increased to $109(38 \cdot 1 \%)$ in all the leprous patients. When only the eyes with established CPI were included 58 patients (49.2\%) out of 118 with CPI were found to have an IOP below $10 \mathrm{mmHg}$. In $51(30.4 \%)$ out of 168 eyes with negative CPI the IOP was found to be below $10 \mathrm{mmHg}$ (Tables 4 and 5).

\section{Discussion}

Leprosy affects the eye by multiplication of leprous bacilli and by spreading through the body via the blood stream in patients with a deficient cellular immune response. The bacillus may be present in any part of the eye, but the lesions it causes are almost always localised in the anterior segment. It is presumed that the earliest affected part of the eye is the ciliary body. Bacteria pass from there to the surrounding tissues by way of the blood stream, nerves, and adjacent tissues. ${ }^{12}$

Especially in patients with $\mathrm{LL}$ and $\mathrm{BL}$,

Table 3 The relation between the duration of leprosy and intraocular pressure (IOP)

\begin{tabular}{lllll}
\hline $\begin{array}{l}\text { Duration of } \\
\text { disease }\end{array}$ & $\begin{array}{l}\text { Age }(y r) \\
\text { mean }(S D)\end{array}$ & $n$ & $\begin{array}{l}\text { IOP mmHg } \\
\text { mean }(S D)\end{array}$ & $p$ \\
\hline $0-5$ & $33 \cdot 5(18 \cdot 1)$ & 36 & $12 \cdot 3(4 \cdot 6)$ & - \\
$6-10$ & $32 \cdot 5(8 \cdot 6)$ & 56 & $11 \cdot 1(4 \cdot 0)$ & $>0.05$ \\
$11-15$ & $39 \cdot 2(12 \cdot 6)$ & 28 & $11 \cdot 0(1 \cdot 9)$ & $>0 \cdot 05$ \\
$16-20$ & $39 \cdot 1(11 \cdot 3)$ & 48 & $9 \cdot 5(2 \cdot 1)$ & $<0 \cdot 001$ \\
$>20$ & $49 \cdot 8(9 \cdot 3)$ & 118 & $10 \cdot 3(3 \cdot 3)$ & $<0.005$ \\
\hline
\end{tabular}

'erythema nodosum leprosum' (or type II reaction, another name for it), which is a systemic immune complex disease, may develop by the antigenic effect of the leprosy bacilli. During this event the testicles, joints, and kidneys become involved together with the eyes. ${ }^{6}$ Acute nongranulomatous iridocyclitis develops in the eye. Moreover, chronic granulomatous lepromatous iritis also develops after the invasion of the leprosy bacillus. ${ }^{2}$

It has been presumed that these recurrent uveitis attacks, which have an insidious and continuous course, affect the secretory epithelium in the ciliary body and prevent its proper functioning. There have been reports which demonstrate the frequency of these recurrent iridocyclitis attacks and the disturbance of the dynamics in aqueous humour. ${ }^{78}$

Histopathological studies carried out in the iris and ciliary body of the eyes involved in iridocyclitis have demonstrated epithelial damage, widespread mononuclear cell infiltration in the stroma, hyalinisation, fibrosis, and atrophy. ${ }^{\text {? }}$ In another study it has been reported that in patients with Behçet's disease the $c$ value has been lowered to pathological levels in the eyes with more than five attacks, and that secondary glaucoma appeared in only a small number of these eyes; the reason for this has maybe the decrease in the secretory rate. ${ }^{8}$ Slem has also reported that production of aqueous humour is significantly lowered in patients with leprosy. ${ }^{9}$

Brandt $e t \mathrm{al}^{3}$ reported that they found CPI in $22 \cdot 3 \%$ of cases with lepromatous leprosy, and suggested that the IOP is lower in the eyes with CPI than in eyes without it.

In our study we found CPI in $41 \cdot 2 \%$ of cases of leprosy, and the mean IOP in these cases was

Table 4 The distribution of lower IOP values in leprosy patients in control group

\begin{tabular}{lll}
\hline $\begin{array}{l}\text { IOP } \\
m m H g\end{array}$ & $\begin{array}{l}\text { Leprosy Patients } \\
n=268\end{array}$ & $\begin{array}{l}\text { Control group } \\
n=48\end{array}$ \\
\hline$\leqslant 5$ & $12(4 \cdot 2)^{\star}$ & - \\
$6-7$ & $34(11 \cdot 9)$ & - \\
$8-9$ & $63(22 \cdot 0)$ & $7(14 \cdot 5)$ \\
$\geqslant 10$ & $177(61 \cdot 9)$ & $41(85 \cdot 5)$ \\
\hline
\end{tabular}

Percentages in brackets

Table 5 The distribution of lower IOP values $(<10 \mathrm{mmHg})$ in leprosy patients with and without CPI, and control group

\begin{tabular}{lll}
\hline & \multicolumn{3}{l}{$I O P<10 m m H g$} \\
\cline { 2 - 3 } & $n$ & $\%$ \\
\hline CPI (+) leprosy eyes $n=118$ & 58 & $49 \cdot 2$ \\
CPI (-) leprosy eyes $n=168$ & 51 & $30 \cdot 4$ \\
Normal control group $n=48$ & 7 & $14 \cdot 5$ \\
\hline
\end{tabular}


significantly lower than in the control group or in patients with CPI. There was a statistically significant difference between the IOP in patients with leprosy but without CPI and the control group. We have assumed that there are two reasons for this condition. The first is that, since iridocyclitis does not always cause persistent lesions, these eyes have in fact, had iridocyclitis attacks but without sequelae. Further, we presume that the bacillus has involved the autonomic nervous system ${ }^{10}$ and has affected neurogenous mechanisms of the aqueous humour dynamics. More probably, these two mechanisms both cause the decrease in IOP, even if at a lower level, which we have found in the eyes with non-established findings of CPI.

Consequently, the IOPs of patients with lepromatous leprosy and borderline lepromatous leprosy were lower than in the normal group. This decrease in the IOP was more in the eyes where findings of CPI have been established, and this condition can be explained by inflammation decreasing the inflow. There was a decrease of IOP in the eyes in which objective findings as to the CPI were not established as compared to the ones with established CPI symptoms. This suggests that hypotonicity related to leprosy cannot be attributed only to uveitis.

1 Brand ME, ffytch TJ. Eye complications of leprosy. In: Hastings RC, ed. Leprosy. Edinburgh, London: ChurchillLivingstone, 1985; 223-42.

2 Karaçorlu MA, Cakıner T. Lepra hastalığında göz problemleri. In: Saylan T, Sütlas M, Yaylacık Matbaası, eds. II. Ulusal In: Saylan T, Sütlaş M, Yaylackk Matbas

3 Brandt F, Malla OK, Anten JGF. Influence of untreated chronic plastic iridocyclitis of intraocular pressure in leprous patients. Br f Ophthalmol 1981; 65: 240-2.

4 Aytekin H, Saylan T. Türkiye'de lepra (I). In: Saylan T, Sütlas M, Yaylacik Matbaasi, eds. II. Ulusal Lepra Semineri. Istanbul: 1986: $51-63$.

5 Jopling WH. Handbook of leprosy. 2nd ed. London: Heinemann, 1978: 18-41.

6 Ridley DS. Leprada histologinin uygulanması, tanı, sıniflandırma ve reaksiyonlar. In: Saylan $T$, Sütlaş $M$. Yaylacik Matbassi, eds. Istanbul: 1986: 90-1.

7 Kozakoğlu H, Akışık K. Behçet Hastalığında hümör aköz dinamiğinin incelenmesi. Deri Hastalıklan ve Frengi Arçivi 1986; 20: 127-37.

8 Oğuz V, Pazarlı H, Abidinia S, Özyazgan Y. Evaluation de la relation entre le nombre d'attaques et le glaucome secondaire de la maladie de Behçet. Bull Soc Ophthalmol Fr in press.

9 Slem G. Clinical studies of ocular leprosy. Am $\mathcal{f}$ Ophthalmol $1971 ; 100: 431-4$

10 Karaçorlu M, Sürel Z, Çakıner T, Hanyaloğlu F, Saylan T, Mat C. Pupil cycle time and early autonomic involvement in ocular leprosy. $\mathrm{Br} \mathcal{F}$ Ophthalmol in press. 